\title{
Modulatory action of Helicobacter pylori on histamine release from mast cells and basophils in vitro
}

\author{
DEBORAH A. LUTTON* $\dagger$, KATHLEEN B. BAMFORD $\dagger$, B. O'LOUGHLIN $\dagger$ and MADELEINE ENNIS*
}

Departments of ${ }^{*}$ Clinical Biochemistry and $\dagger$ Microbiology and Immunology, The Queen's University of Belfast, Belfast

\begin{abstract}
Summary. Helicobacter pylori is important in the aetiology of peptic ulceration. Despite inducing an inflammatory response in the mucosa, the organism persists, suggesting that it has efficient protective mechanisms. Some bacterial and viral products modulate histamine secretion from inflammatory cells. Therefore, this study examined the modulatory effects of $H$. pylori preparations on histamine release from rat peritoneal mast cells and human basophils. Eleven clinical isolates of $H$. pylori were prepared in different ways: as whole washed bacteria, washed sonicated bacteria, and formalin-killed bacteria, and as outermembrane and lipopolysaccharide (LPS) extracts. Histamine release from mast cells or basophils was not elicited by any of these bacterial preparations alone. However, when mixed with various secretory stimulants, the bacterial preparations caused inhibition of histamine release from rat mast cells (calcium ionophore A23187, compound 48/80, concanavalin A, anti-rat IgE) and human basophils (A23187, N-formyl Met-Leu-Phe). The degree of inhibition ranged from $48 \%$ to $97 \%$. These results indicate that $H$. pylori exerts an inhibitory effect on cells of the immune system that contributes to its persistence within the gastric mucosa.
\end{abstract}

\section{Introduction}

Helicobacter pylori $(H$. pylori) is recognised as a significant cause of chronic antral gastritis and is important in the aetiology of duodenal ulceration. ${ }^{1-3}$ There is also evidence to support a role for $H$. pylori as a risk factor for gastric carcinoma. ${ }^{4-6}$ The pathogenic mechanisms of $H$. pylori are incompletely understood. Several of the histological features associated with H. pylori infection (e.g., neutrophil infiltration and increased numbers of mononuclear cells - chiefly lymphocytes and plasma cells) are similar to those observed in human allergic reactions. ${ }^{7,8}$ The importance of mast cells and basophils in immediate hypersensitivity reactions (e.g., hay fever, atopic asthma) has long been recognised ${ }^{9}$ and recent evidence suggests that they may be involved in other disease states involving chronic inflammatory processes. ${ }^{10}$ Mast cells and basophils may be activated either by immunological mechanisms (via antigen cross-linking of specific IgE bound to the plasma membrane of mast cells and basophils) or via non-immunological pathways, whereby the agent directly activates the

Received 15 Aug. 1994; revised version accepted 30 Nov. 1994. ‡ Correspondence should be sent to Dr M. Ennis. cells. ${ }^{11}$ Haemophilus influenzae, Salmonella typhimurium and several other bacteria, as well as bacterial and viral products, have been found to induce or modulate histamine release from mast cells or basophils. ${ }^{12,13}$

Duodenal ulcer patients, both children ${ }^{14}$ and adults, ${ }^{15}$ with $H$. pylori infection have a lower concentration of histamine within their oxyntic mucosa than $H$. pylori-negative patients. This suggests that the mucosal mast cells in the $H$. pylori-positive patients are either actively secreting histamine, or that histamine synthesis is reduced. Furthermore, basophils from $84 \%$ of chronic gastritis patients with $H$. pylori infection were found to have bound $H$. pylori-specific IgE, and to release histamine when challenged with surface antigens of $H$. pylori. Histamine liberation, by an IgE-mediated mechanism, was similarly achieved when normal basophils were passively sensitised with serum from IgE-positive patients. ${ }^{16}$

In-vitro studies have shown that washed cells, formalin-killed cells and crude cell-wall preparations of $H$. pylori were unable to induce histamine release from rat serosal, peritoneal and pleural mast cells. However, similar preparations from several $H$. pylori strains were found to potentiate mast cell histamine release induced by compound $48 / 80$, calcium 
ionophore A23178 and cholic acid. ${ }^{17,18}$ Enhancement was maximal with the crude cell-wall preparations and differences in the degree of histamine release were obtained with different strains of $H$. pylori.

Thus, $H$. pylori may be involved in mast cell and basophil activation and subsequent mediator release. In patients with specific IgE, an antibody-allergen reaction may occur leading to mediator release and the attendant inflammatory response. However, in patients lacking specific IgE, $H$. pylori products may potentiate the release of mediators from mast cells or basophils which have been primed by other agents. Despite these studies, the precise role of $H$. pylori in histamine release remains unclear.

The aim of the present study was to investigate further the direct and modulatory actions of $H$. pylori preparations on rat peritoneal mast cells and human basophils. The effect of $H$. pylori on mediator release via both IgE-dependent and IgE-independent nonimmunological mechanisms was examined.

\section{Materials and methods}

\section{Isolation, characterisation and culture of $H$. pylori}

Antral biopsy specimens from patients were inoculated directly on to Columbia Agar Base (Oxoid) containing defibrinated horse blood $7 \% \mathrm{v} / \mathrm{v}$ and on to agar with antibiotic supplement (vancomycin $10 \mathrm{mg} / \mathrm{L}$, trimethoprim lactate $5 \mathrm{mg} / \mathrm{L}$, cefsulodin $5 \mathrm{mg} / \mathrm{L}$, amphotericin $\mathrm{B} 5 \mathrm{mg} / \mathrm{L}$ and nalidixic acid $20 \mathrm{mg} / \mathrm{L}$ ). Plates were incubated at $37^{\circ} \mathrm{C}$ for up to 5 days in a micro-aerophilic atmosphere of $\mathrm{O}_{2} 5 \%$, $\mathrm{H}_{2} 1 \%, \mathrm{CO}_{2} 7 \%$ and $\mathrm{N}_{2} 87 \%$ (variable atmosphere incubator; Don Whitley Scientific, Shipley, W. Yorks). Isolates were identified as $H$. pylori if they were gram-negative with a typical morphology, hydrolysed urea rapidly and were catalase- and oxidase-positive. ${ }^{19}$ The identification was confirmed by gene amplification by the polymerase chain reaction. ${ }^{20}$ Isolates were stored at $-70^{\circ} \mathrm{C}$ in peptone $1 \%$ $\mathrm{w} / \mathrm{v}$ solution containing glycerol $25 \% \mathrm{v} / \mathrm{v}$.

For control experiments, a recently isolated noncapsulate strain of Hae. influenzae was grown aerobically for $24 \mathrm{~h}$ at $37^{\circ} \mathrm{C}$ on Columbia chocolate agar, which was made by adding defibrinated horse blood $7 \% \mathrm{v} / \mathrm{v}$ to Columbia agar base and heating at $75^{\circ} \mathrm{C}$ for $30 \mathrm{~min}$.

\section{Preparation of bacteria for histamine release experiments}

For whole washed H.pylori, bacteria were harvested after 2-3 days, washed three times in $0.01 \mathrm{M}$ phosphatebuffered saline, $\mathrm{pH} 7.4$ (PBS), and resuspended in Tyrode's buffer.$^{21}$ Sonicated bacteria were prepared by sonication on ice, three times for $2 \mathrm{~min}$ at an amplitude of $18 \mu \mathrm{m}$ (MSE Soniprep 150). These H. pylori preparations were used at a final protein concentration of $0.15 \mathrm{mg} / \mathrm{ml}$, which was chosen as appropriate from the previously published work of Bechi et al. ${ }^{17}$
Formalin-killed $H$. pylori were obtained by incubation of whole bacteria in formalin $2 \% \mathrm{v} / \mathrm{v}$ in PBS for $1 \mathrm{~h}$ at $37^{\circ} \mathrm{C}$. The bacteria were subsequently washed four times in PBS and resuspended in Tyrode's buffer to a final concentration of $10 \mathrm{mg}$ wet weight $/ \mathrm{ml}$ as used in previous studies by Stahl Skov et al. ${ }^{22}$

Bacterial outer membranes were extracted by suspension of whole washed $H$. pylori in $N$-lauroyl sarcosinate $3 \% \mathrm{v} / \mathrm{v}$ for $1 \mathrm{~h}$ with rotation. ${ }^{23}$ The extraction mixture was then centrifuged $(12000 \mathrm{~g}, 1 \mathrm{~h}$, $4^{\circ} \mathrm{C}$ ) and the pellet was resuspended in Tyrode's buffer to a final concentration of $10 \mu \mathrm{g}$ of protein $/ \mathrm{ml} .^{24}$ Lipopolysaccharide (LPS) was extracted by the proteinase $\mathrm{K}$ method of Clementsen et $_{\text {al }}{ }^{25}$ and Brown $e t$ $a l .{ }^{26}$ Briefly, whole washed $H$. pylori cells were suspended in Tris buffer $(1.5 \mathrm{ml}, 0.025 \mathrm{M}, \mathrm{pH} 7.4)$ to an absorbance of 0.6 at $525 \mathrm{~nm}$. They were then incubated $\left(1 \mathrm{~h}, 37^{\circ} \mathrm{C}\right)$ with an insoluble proteinase $\mathrm{K}$-agarose compound ( $25 \mu \mathrm{g}$; Sigma P-9290). The enzymeagarose complex was removed by centrifugation $\left(200 \mathrm{~g}, 5 \mathrm{~min}, 4^{\circ} \mathrm{C}\right)$ and any possible remaining enzyme activity in the supernate was inactivated by heating $\left(30 \mathrm{~min}, 70^{\circ} \mathrm{C}\right)$. The supernate preparation was then diluted 1 in 4 in Tyrode's buffer for use in the histamine release experiments, as recommended by Professor S. Norn (personal communication).

Hae. influenzae was harvested at $24 \mathrm{~h}$, washed three times in PBS and resuspended in Tyrode's buffer. The bacteria were used in the histamine release assay at a final protein concentration of $0.15 \mathrm{mg} / \mathrm{ml}$, as above.

\section{Isolation of human basophils}

Blood $(30 \mathrm{ml})$ was drawn by venepuncture, anticoagulated with heparin, and mixed with $5 \mathrm{ml}$ of dextran 70 (Lomodex 70) and $150 \mathrm{mg}$ of glucose. After sedimentation for $90 \mathrm{~min}$, the supernate was collected. The cells were obtained by centrifugation $(200 \mathrm{~g}$, $7 \mathrm{~min}, 20^{\circ} \mathrm{C}$ ), and washed twice in Tyrode's buffer. The basophils were pre-incubated at $37^{\circ} \mathrm{C}$ for $10 \mathrm{~min}$ before challenge.

\section{Isolation of rat peritoneal mast cells}

Mixed peritoneal cells were isolated from female Hooded Lister rats by direct lavage with heparinised Tyrode's buffer as described previously. ${ }^{21}$ The mast cell suspensions were pre-warmed for $5 \mathrm{~min}$ at $37^{\circ} \mathrm{C}$ before challenge.

\section{Histamine release assay}

Mast cells or basophils were incubated, for 10 and $45 \mathrm{~min}$, respectively, with the various bacterial preparations alone, or in the presence of several known immunological or non-immunological stimulants (as described in the Results). All samples were incubated, in duplicate, at $37^{\circ} \mathrm{C}$ within a metabolic shaker. The reactions were stopped by placing the tubes in an icewater bath and the addition of ice-cold Tyrode's buffer. The cells were recovered by centrifugation, and 
the histamine concentration was assayed in both the cellular and the supernatant (released histamine) fractions. Histamine was measured by an automated fluorimetric assay based on the method of Shore et al. ${ }^{27,28}$

Histamine release was expressed as a percentage of the total histamine (cells and supernates) and corrected for the spontaneous release (i.e., that occurring in the absence of a stimulant). In several experiments, the effects of $H$. pylori preparations on histamine release were expressed as percentage inhibition. This was calculated from the formula:

$$
\begin{aligned}
& \text { Inhibition }(\%)= \\
& \qquad 100-\left[\frac{\text { in the presence of } H \cdot \text { pylori }}{\text { histamine release by secretagogue }}\right. \\
& \left.\left.\begin{array}{c}
\text { histamine release by } \\
\text { secretagogue alone }
\end{array}\right] 100\right]
\end{aligned}
$$

Data are given as means and standard error of the mean (SEM) for the number ( $n$ ) of experiments performed, unless otherwise stated.

\section{Results}

In the initial experiments, whole washed bacteria of 11 different strains of $H$. pylori were tested. None of the strains elicited a significant histamine release from rat peritoneal mast cells when tested alone and, therefore, two $H$. pylori strains (HP1 and HP2) were selected for the further experiments.
Table. Effect of different concentrations of whole washed $H$.

\begin{tabular}{|c|c|c|}
\hline \multirow{2}{*}{$\begin{array}{c}\text { Protein } \\
\text { concentration } \\
(\mathrm{mg} / \mathrm{ml})\end{array}$} & \multicolumn{2}{|c|}{ Mean (SEM) percentage histamine release } \\
\hline & $H$. pylori alone & $\begin{array}{l}\text { H. pylori plus } \\
\text { A23187 }\end{array}$ \\
\hline 0 & 0 & $29 \cdot 6(5.9)$ \\
\hline 0.005 & $1 \cdot 5(1 \cdot 1)$ & $29 \cdot 5(5 \cdot 1)$ \\
\hline $0 \cdot 01$ & $-0.2(0.2)$ & $26 \cdot 7(5 \cdot 3)$ \\
\hline 0.025 & $0.8(0.3)$ & $13 \cdot 3(4 \cdot 6)$ \\
\hline $0 \cdot 05$ & $0.6(0.6)$ & $6.7(1.8)$ \\
\hline $0 \cdot 1$ & $2 \cdot 5(1 \cdot 4)$ & $8 \cdot 6(3 \cdot 5)$ \\
\hline
\end{tabular}
pylori (strain HP1) on histamine release from rat peritoneal mast cells induced by calcium ionophore A23187 (0.25 $\mu \mathrm{M})$

*All data are given as means (SEM) for 4-5 experiments. Negative values occur when the histamine release in the presence of bacteria is less than that obtained for the spontaneous release.

No significant histamine release $(<3 \%)$ was induced when $H$. pylori preparations HP1 and HP2 (whole washed or sonicated cells) were incubated alone with rat peritoneal mast cells (data not shown). However, these preparations inhibited histamine release induced by either calcium ionophore A23187 or compound 48/80 (fig. 1). There was a concentrationdependent inhibition of histamine release (table). In all experiments with whole washed bacteria, preparations were standardised to $0.15 \mathrm{mg}$ of protein $/ \mathrm{ml}$. This value was chosen in light of the data of Bechi et al. ${ }^{17}$ who studied the dose response effects of similar bacterial preparations. A further nine randomly selected clinical isolates of $H$. pylori (HP3-HP11) inhibited histamine

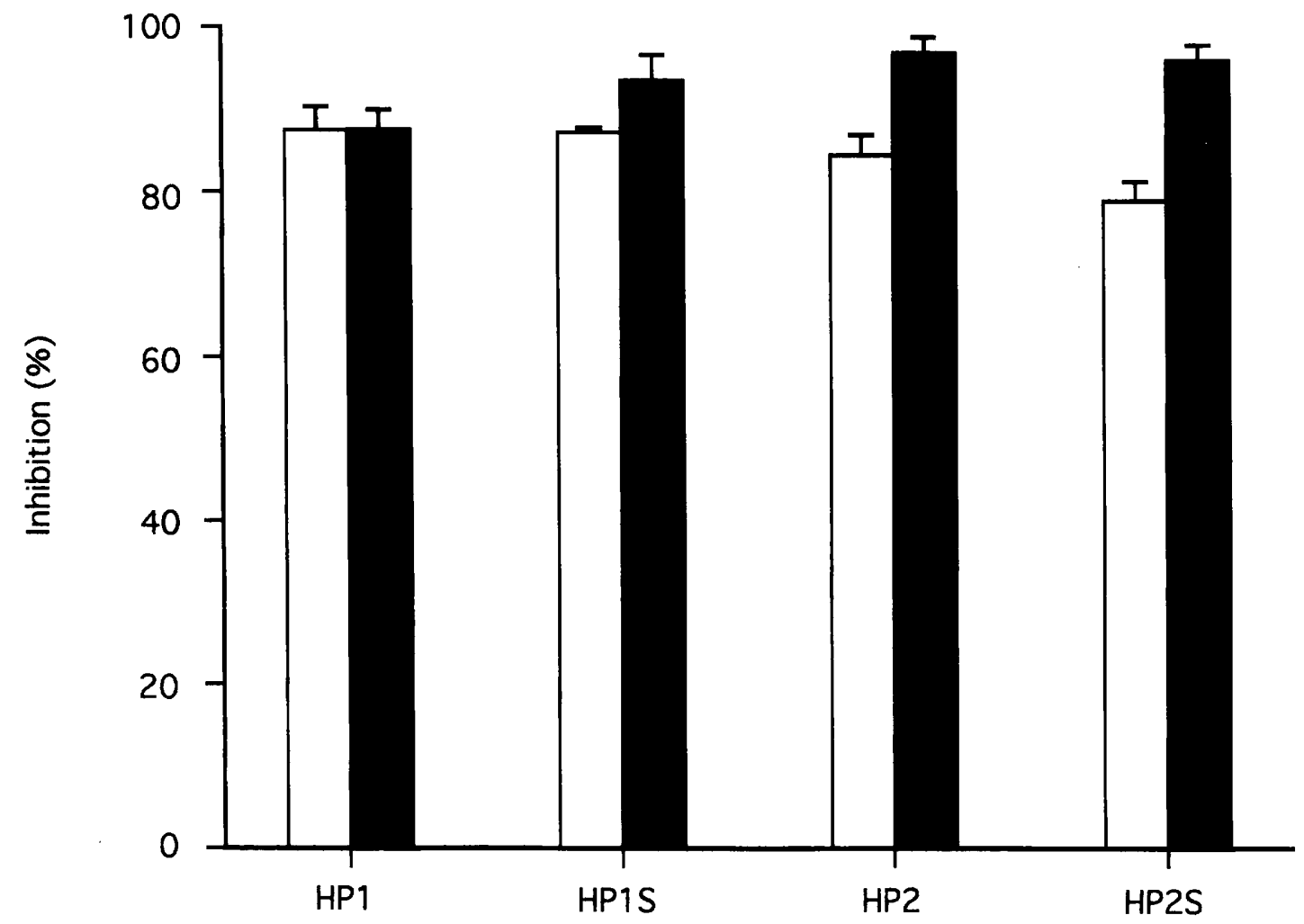

Fig. 1. Inhibitory effects of whole washed (HP1 and HP2) and sonicated (HP1S and HP2S) preparations of two strains of $H$. pylori on histamine release from rat peritoneal mast cells induced by calcium ionophore $\mathrm{A} 23187(0 \cdot 25 \mu \mathrm{M}, \square)$ or compound $48 / 80(0 \cdot 04 \mu \mathrm{g} / \mathrm{ml}, \square)$. Values shown are means (and SEM) of four experiments, each performed in duplicate. The histamine release values in the absence of $H$. $p y l o r i$ preparations were 61.0 SEM 2.9\% (calcium ionophore A23187) and 20.7 SEM 2.5\% (compound 48/80). 


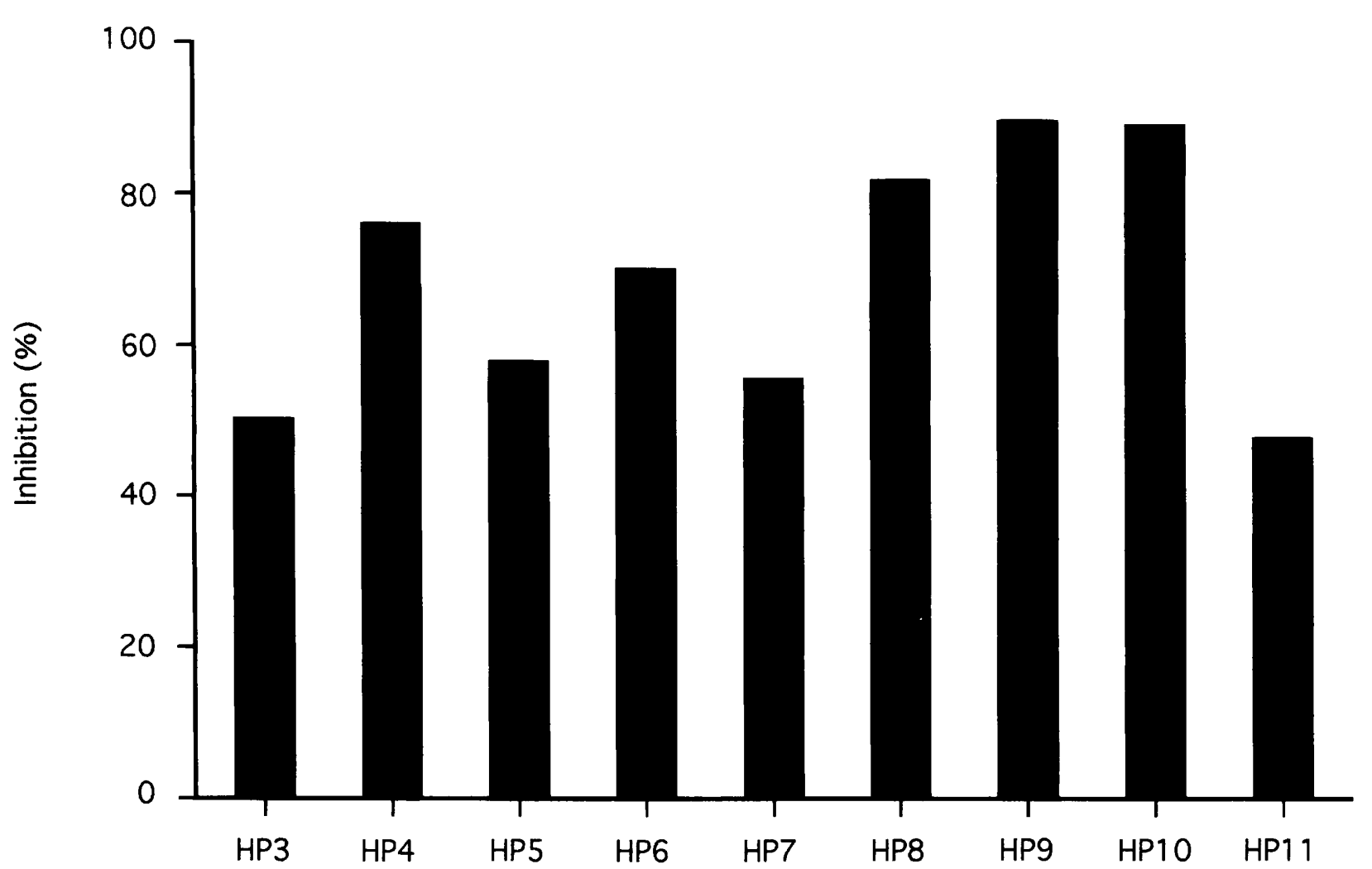

Fig. 2. Comparison of the inhibitory effects of different clinical isolates of whole washed $H$. pylori (HP3-HP11) on histamine release from rat peritoneal mast cells induced by calcium ionophore A23187 $(0.25 \mu \mathrm{M})$. The control histamine release values in the absence of $H$. pylori preparations were $37.6 \%$ and $81.1 \%$ for the experiments involving strains HP3-HP7 and HP8-HP11, respectively.

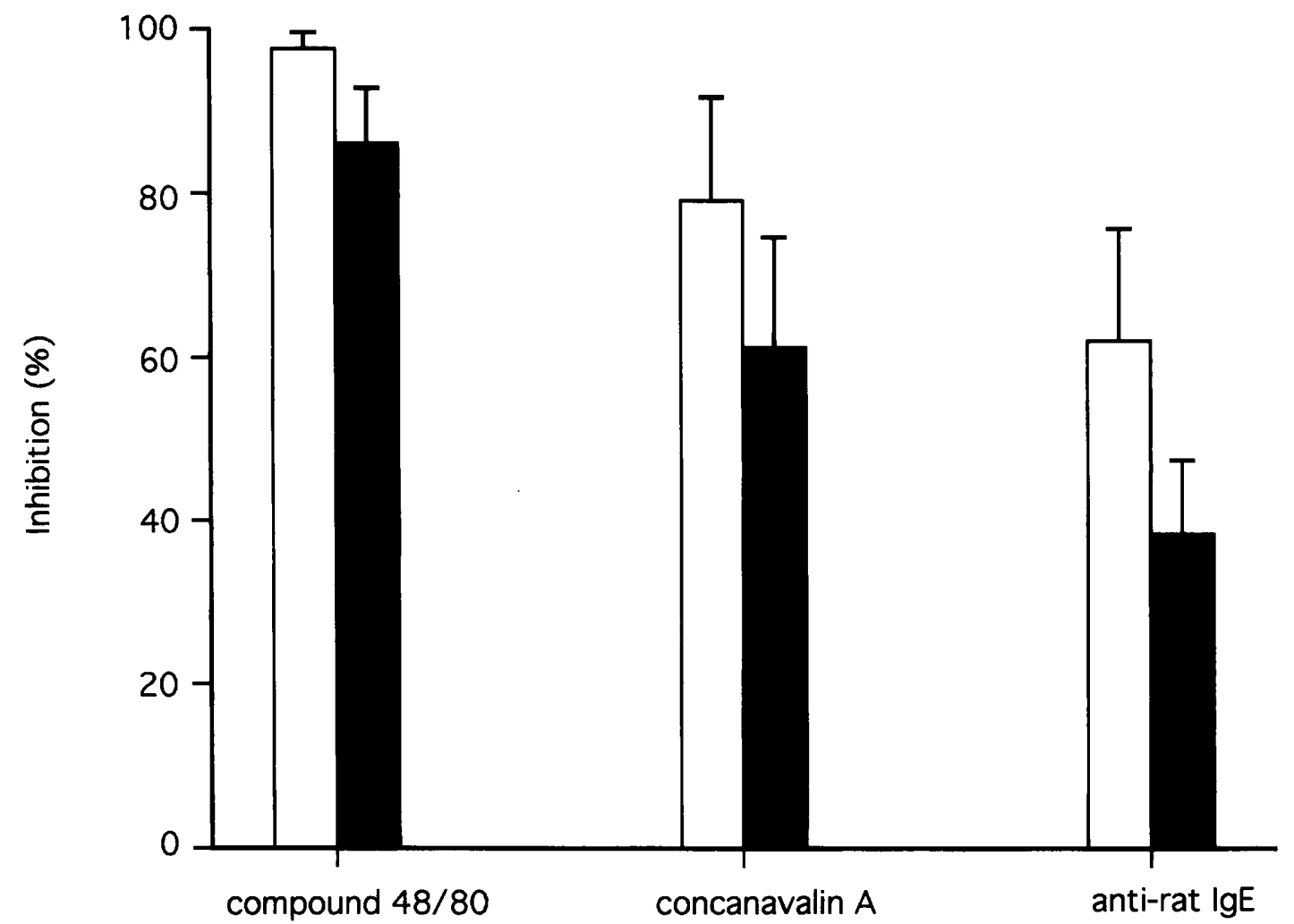

Fig. 3. Inhibitory effects of formalin-killed preparations $(\square)$ or LPS extracts $(\square)$ of $H$. pylori (HP1) on histamine release from rat peritoneal mast cells induced by compound 48/80 $(0.1 \mu \mathrm{g} / \mathrm{ml})$, concanavalin $\mathrm{A}(1 \mu \mathrm{g} / \mathrm{ml})$ or anti-rat $\mathrm{IgE}(1 \mathrm{in} 5000$ dilution). Values shown are means (and SEM) for three experiments, each performed in duplicate. The histamine release values in the absence of $H$. pylori preparations were 44.6 SEM 2.5\% (compound 48/80), 37.3 SEM 10.1\% (concanavalin A) and 40.4 SEM 15.2\% (anti-rat IgE).

release induced by calcium ionophore A23187. The inter-strain variation in this inhibition of histamine release by $H$. pylori is illustrated in fig. 2 .

The effects of formalin-killed bacteria, outer- membrane preparations and LPS extracts of $H$. pylori (HP1) were examined. Minimal histamine release was induced $(<10 \%)$ when these preparations were incubated alone with rat peritoneal mast cells (data 


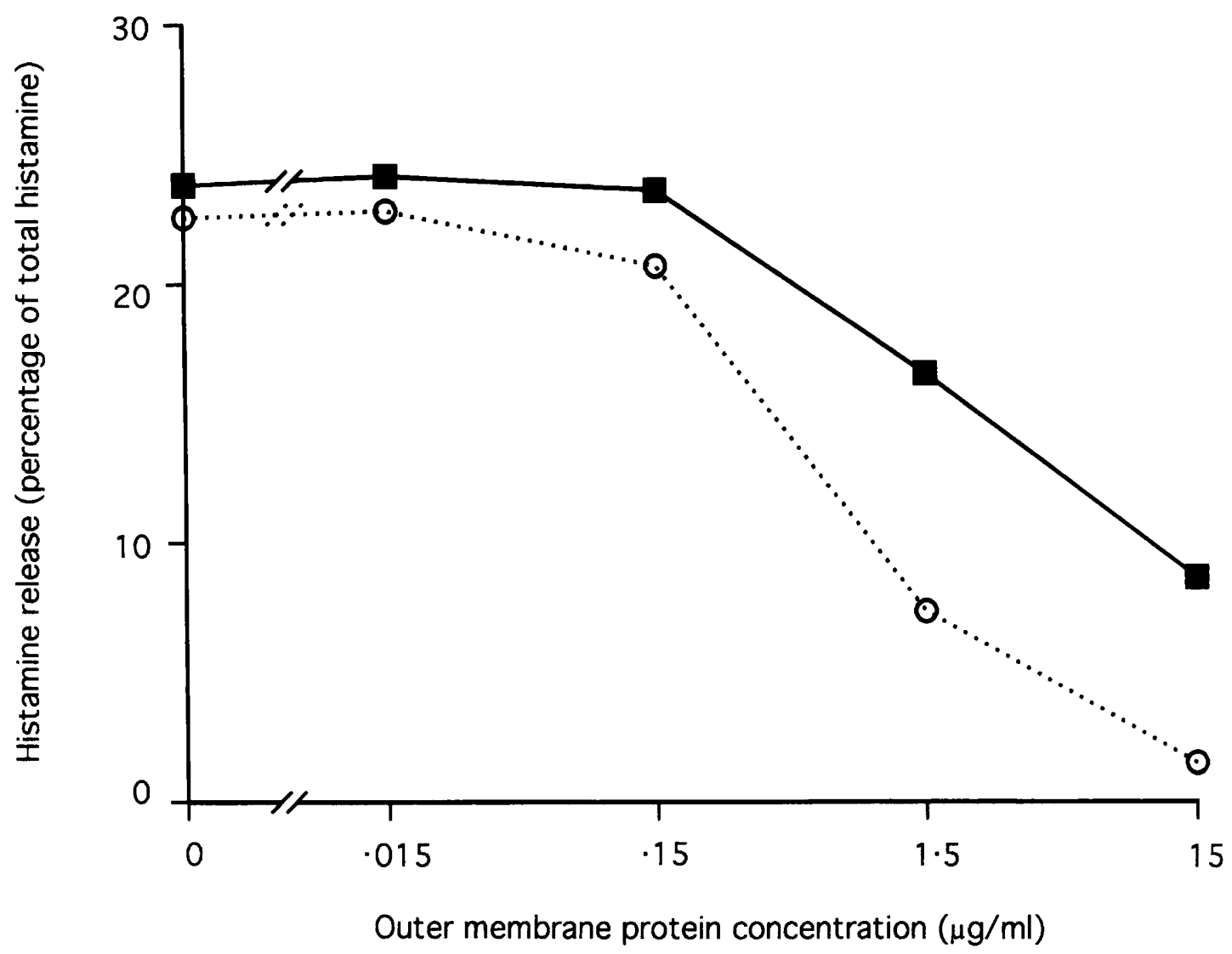

Fig. 4. Effect of different concentrations of outer membrane preparations of $H$. pylori on histamine release from rat peritoneal mast cells induced by the calcium ionophore A23187 $(0 \cdot 25 \mu \mathrm{M},-\square-)$ or compound $48 / 80(0 \cdot 4 \mu \mathrm{g} / \mathrm{ml}, \cdots \odot \cdots)$.

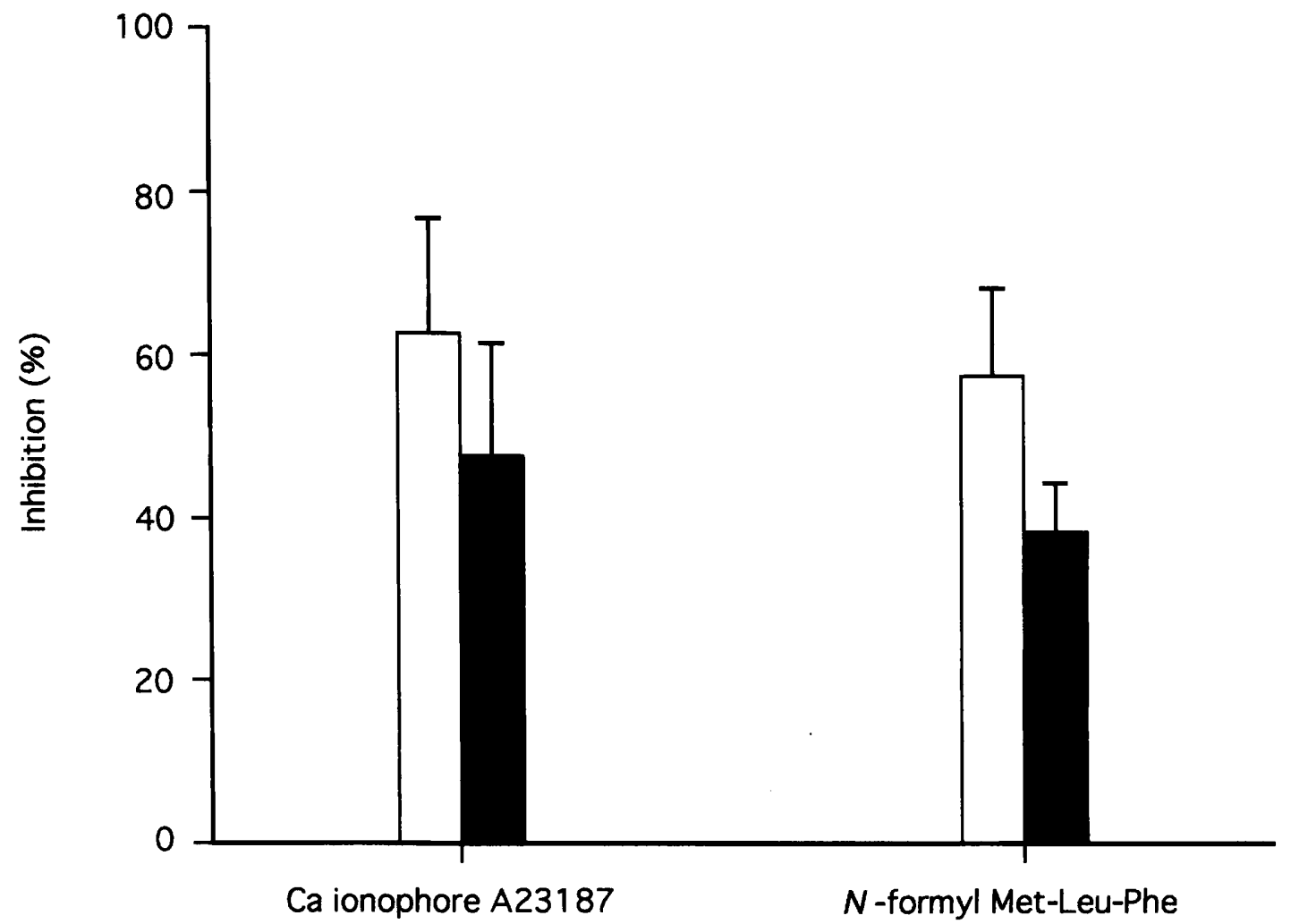

Fig. 5. Inhibitory effects of formalin-killed preparations ( $\square$ ) or LPS extracts ( $\square$ ) of $H$. pylori (HP1) on histamine release from human basophils induced by calcium ionophore A23187 $(0 \cdot 25 \mu \mathrm{M})$ or $N$-formyl Met-Leu-Phe (0.01 $\mu \mathrm{M})$. Values shown are means (and SEM) for 5-6 experiments, each performed in duplicate. The histamine release values in the absence of $H$. pylori preparations were $32 \cdot 1 \mathrm{SEM} 3 \cdot 1 \%$ (calcium ionophore A23187) and 15.2 SEM 1.3\% ( $N$-formyl Met-Leu-Phe). 
not shown). Histamine release induced by compound $48 / 80$, concanavalin A, or anti-rat IgE was inhibited by formalin-killed preparations and LPS extracts of H. pylori (fig. 3). H. pylori outer-membrane preparations caused a dose-dependent inhibition of histamine release induced by compound $48 / 80$ and A23187 (fig. 4).

With human basophils, no significant histamine release $(<3 \%)$ was induced when formalin-killed preparations or LPS extracts of $H$. pylori (HP1) were incubated alone with these cells (data not shown). These preparations inhibited histamine release from human basophils induced by calcium ionophore A23187 and $N$-formyl Met-Leu-Phe (fig. 5). H. pylori outer-membrane preparations ( $10 \mathrm{ng}$ of protein $/ \mathrm{ml}$ ) caused a slight but significant inhibition $(17 \%)$ of A23187-induced histamine release but higher concentrations were not tested.

No significant histamine release was obtained when whole washed Hae. influenzae were incubated alone with rat peritoneal mast cells. The histamine release induced by calcium ionophore A23187 $(0.25 \mu \mathrm{M})$ was approximately doubled (from $13 \%$ to $23 \%$ ) by co-incubation with Hae. influenzae $(0.15 \mathrm{mg}$ of protein $/ \mathrm{ml}$ ).

\section{Discussion}

Histamine plays an essential role in the regulation of gastric acid secretion. ${ }^{29}$ Factors that stimulate the production or liberation of histamine may contribute to the pathogenesis of duodenal ulcer disease, which is characterised by gastric hypersecretion. $H$. pylori is known to be an important pathogen in duodenal ulcer disease ${ }^{30}$ however, the influence of $H$. pylori on mast cell and basophil histamine release remains unclear.

Previous findings ${ }^{17,18}$ that histamine liberation does not occur when whole washed, whole formalin-killed or crude cell-envelope extracts of $H$. pylori are incubated in vitro with rat peritoneal mast cells were confirmed. This work was extended and it was found that, in addition, histamine release was not induced when rat peritoneal mast cells were exposed to LPS or outer-membrane extracts of $H$. pylori. Furthermore, in similar experiments with human basophils, histamine release was not stimulated by incubation with LPS or whole formalin-killed H. pylori preparations. However, in contrast to previous reports, ${ }^{17,18}$ each of the five $H$. pylori preparations studied was shown to inhibit the release of histamine from rat peritoneal mast cells simultaneously stimulated by calcium ionophore A23187 or compound 48/80. Inhibition was consistently obtained with whole washed bacteria of each of 11 different clinical isolates of $H$. pylori. The Italian workers found that co-incubation of purified rat peritoneal mast cells with several strains of $H$. pylori (whole washed, whole formalin-killed or crude cell-envelope preparations) and calcium ionophore A23187 or compound $48 / 80$, caused a marked potentiation of histamine release. ${ }^{17,18}$ In the present study, inhibition of histamine release from rat peritoneal mast cells was also seen with other stimulants (anti-rat IgE, concanavalin A) and with an additional cell type, the human basophil (calcium ionophore A23187, $N$-formyl Met-Leu-Phe). Where possible, the concentration of bacterial preparations used was one that produced potentiation in previous studies. ${ }^{17,18}$

This inconsistency in the modulatory effects of $H$. pylori preparations on histamine release may reflect variations between the strains of $H$. pylori isolated in two different countries (Italy ${ }^{17,18}$ and Northern Ireland). It is known that there is considerable genetic variation between different isolates of $H$. pylori. ${ }^{31,32}$ The modulatory effect of $H$. pylori was found previously to differ between strains and, in some strains, no significant potentiation of histamine release was obtained. ${ }^{17}$ However, in the present study inhibition of histamine liberation was obtained with each of 11 different clinical isolates of $H$. pylori $(48-97 \%$ inhibition). Although, in the current study, unpurified target cell populations were used, it is unlikely that the different effect was due to problems associated with either the cells or test systems examined, as potentiation of histamine liberation from rat peritoneal mast cells was achieved after co-incubation with calcium ionophore A23187 and Hae. influenzae. This is in agreement with a previous study in which calcium ionophore A23187 enhanced histamine release from human basophils after stimulation with endotoxin from Hae. influenzae. ${ }^{13}$

The differences observed in the action of $H$. pylori preparations may also be due to the isolation procedures for the rat peritoneal mast cells. In the present study the cells were not purified, as marked functional alterations can occur after purification by density gradient methods. ${ }^{33}$ In contrast, in the previously reported work, cell preparations purified by density gradient centrifugation and elutriation were used. ${ }^{17,18}$

Variation in the modulatory potential of $H$. pylori may reflect differences employed in the in-vitro growth conditions of the bacterium. H. pylori was harvested from solid culture media in the present study, whereas previous investigations were performed with broth cultures. ${ }^{17,18} \mathrm{H}$. pylori strains cultured on a solid medium synthesise Paf-acether, whereas the same isolates cultured in brucella broth do not. ${ }^{34}$ Therefore, it would be of interest to compare directly the ability of $H$. pylori isolates grown under different conditions to modulate mediator release.

Investigations of the interactions of $H$. pylori with the host cellular immune system have shown an increase in the expression of class II transplantation antigens and in the proportion of $\gamma / \delta$ T cells in $H$. pylori-infected compared to non-infected mucosa. ${ }^{35,36}$ Stimulation of mononuclear cells, ${ }^{37}$ cytokine production (IL-2, IL-4, IL-6, TNF $\alpha$ ) and soluble CD8 and IL-2 receptor molecule production have been demonstrated in vitro. ${ }^{38,39}$

In contrast, $H$. pylori has been found to exert a 
down-regulating or inhibitory effect on cells involved in the mucosal defences. This includes a reduction in the in-vitro proliferative response of monocytes to stimuli, without altering cell viability. ${ }^{40} \mathrm{~T}$ lymphocyte proliferation is also inhibited and this is associated with a reduction of IL-2 receptor expression. ${ }^{41}$ This, together with the current findings that $H$. pylori inhibits histamine release from mast cells and basophils, may support the theory that the persistence of $H$. pylori infection is related to modulation of the host immune system by this bacterium. Differences in the ability of various $H$. pylori strains to influence the host immune response may influence the outcome of infection. Furthermore, the environmental conditions within the host tissues and the immune status of

\section{References}

1. Marshall BJ, Warren JR, Unidentified curved bacilli in the stomach of patients with gastritis and peptic ulceration. Lancet 1984; 1 : 1311-1315.

2. Goodwin CS, Armstrong JA, Marshall BJ. Campylobacter pyloridis, gastritis and peptic ulceration. J Clin Pathol 1986; 39: 353-365.

3. Soll AH. Pathogenesis of peptic ulcer and implications for therapy. N Engl J Med 1990; 322: 909-916.

4. Forman D, Newell DG, Fullerton F et al. Association between infection with Helicobacter pylori and risk of gastric cancer: evidence from a prospective investigation. $B M J 1991 ; 302$ : 1302-1305.

5. Parsonnet J, Freidman GD, Vandersteen DP et al. Helicobacter pylori infection and the risk of gastric carcinoma. $N$ Engl $J$ Med 1991; 325: 1127-1131.

6. Loffeld RJLF, Willems I, Flendrig JA, Arends JW. Helicobacter pylori and gastric carcinoma. Histopathology 1990; 17: 537-541.

7. Dixon MF, Wyatt JI, Burke DA, Rathbone BJ. Lymphocytic gastritis-relationship to Campylobacter pylori infection. $J$ Pathol 1988; 154: 125-132.

8. Wyatt JI, Rathbone BJ. Immune response of the gastric mucosa to Campylobacter pylori. Scand J Gastroenterol Suppl 1988 142: $44-49$.

9. Norn S, Stahl Skov P, Jensen C, Jarlov JO, Espersen F. Histamine release induced by bacteria. A new mechanism in asthma? Agents Actions $1987 ; 20: 29-34$.

10. Bienenstock J, Befus AD, Denburg JA. Mast cell heterogeneity: basic questions and clinical implications. In: Befus AD, Bienenstock J, Denburg JA (eds) Mast cell differentiation and heterogeneity. New York: Raven Press, 1986: $391-402$.

11. Norn S, Stahl Skov P, Jensen $\mathrm{C}$ et al. Intrinsic asthma and bacterial histamine release via lectin effect. Agents Actions $1983 ; 13: 210-212$

12. Norn S, Jarlov JO, Jensen CB et al. Bacteria and their products peptidoglycan and teichoic acid potentiate antigen-induced histamine release in allergic patients. Agents Actions 1987; 20: 174-177.

13. Norn S, Clementsen P, Fomsgaard A, Kilian M. Haemophilus influenzae potentiates basophil histamine release possibly by its endotoxins. Agents Actions $1990 ; 30: 57-60$.

14. Queiroz DMM, Mendes EN, Rocha GA, Barbosa AJA, Carvalho AST, Cunha-Melo JR. Histamine concentration of gastric mucosa in Helicobacter pylori positive and negative children. Gut 1991; 32: 464-466.

15. Queiroz DMM, Mendes EN, Rocha GA et al. Histamine content of the oxyntic mucosa from duodenal ulcer patients: effects of Helicobacter pylori eradication. $\mathrm{Am} \mathrm{J}$ Gastroenterol 1993; 88: 1228-1232.

16. Aceti A, Celestino D, Caferro $M$ et al. Basophil-bound and serum immunoglobulin $\mathrm{E}$ directed against Helicobacter pylori in patients with chronic gastritis. Gastroenterology 1991; 101: 131-137.

17. Bechi P, Dei R, Di Bello MG, Masini E. Helicobacter pylori the host may influence the expression of virulence determinants by the infecting bacterium. Hence the outcome of infection (chronic gastritis or duodenal ulceration) may reflect a complex series of interactions between the host and the infecting bacterium.

In the present study, $H$. pylori has been shown to inhibit histamine release from rat peritoneal mast cells and human basophils. Further studies are necessary to determine the role of this bacterium in the modulation of histamine release from human mucosal mast cells.

We acknowledge financial support from the Department of Health and Social Services, Northern Ireland and the Friar Fund, Faculty of Medicine, the Queen's University of Belfast. We are grateful to Professor S. Norn (Copenhagen) for his advice on the preparation of bacteria for histamine release studies.

potentiates histamine release from serosal rat mast cells in vitro. Dig Dis Sci 1993; 38: 944-949.

18. Masini E, Bechi P, Dei R et al. Helicobacter pylori potentiates histamine release from rat serosal mast cells. Agents Actions 1993; 38: Special conference issue: C197-199.

19. Megraud F, Bonnet F, Garnier $M$, Lamouliatte $H$. Characterization of "Campylobacter pyloridis" by culture, enzymatic profile, and protein content. J Clin Microbiol 1985; 22 : 1007-1010.

20. Lutton DA, Bamford KB, Collins JSA, O'Loughlin B. Nested primers improve the sensitivity in the detection of $H$. pylori by the polymerase chain reaction. Acta Gastroenterol Belg 1993; 56 Suppl: 58, W.II.6.

21. Ennis M. Laboratory histamine measurements to study type I adverse allergic/pseudoallergic reactions to agents used in anaesthesia and surgery. In: Assem E-SK (ed) Allergic reactions to anaesthetics. Clinical and basic aspects. Monogr Allergy (Basel, Karger) 1986; 30: 74-93.

22. Stahl Skov P, Jensen C, Norn S et al. Possible involvement of lectins in bacteria-induced histamine release in intrinsic asthma. In: Bug-Hansen TC, Spengler GA (eds) Lectins, vol. III. Berlin, Walter de Gruyter. 1983: 27-36.

23. Patrick S, Lutton DA. Outer membrane proteins of Bacteroides fragilis grown in vivo. FEMS Microbiol Lett 1990; 71 : 1-4.

24. Norn S, Clementsen P, Kristensen KS, Hannoun C, Jarløv JO. Carbohydrates inhibit the potentiating effect of bacteria, endotoxin and virus on basophil histamine release. Agents Actions $1990 ;$ 30: 53-56.

25. Clementsen P, Milman N, Kilian M, Fomsgaard A, Baek L, Norn S. Endotoxin from Haemophilus influenzae enhances IgE-mediated and non-immunological histamine release. Allergy 1990; 45: 10-17.

26. Brown $\mathrm{R}$, Hornett KE, Poxton IR. Immunochemistry of the cell surfaces of Bacteroides bivius and Bacteroides disiens. $J$ Med Microbiol 1989; 28: 267-273.

27. Shore PA, Burkhalter A, Cohn VH. A method for the fluorometric assay of histamine in tissues. J Pharmacol Exp Ther 1959; 127: 182-186.

28. Ennis M. Automated fluorometric assays. In: Uvnäs B (ed) Histamine and histamine antagonists. Handbook of experimental pharmacology, 97. Heidelberg, Berlin, Springer-Verlag. 1991: 31-38.

29. Waldum HL, Sandvik AK. Review: Histamine and the stomach. Scand J Gastroenterol 1989; 24: 130-139.

30. Blaser MJ. Helicobacter pylori: its role in disease. Clin Infect Dis $1992 ; 15: 386-391$

31. Owen RJ, Hunton C, Bickley J, Moreno M, Linton D. Ribosomal RNA gene restriction patterns of Helicobacter pylori: analysis and appraisal of HaeIII digests as a molecular typing system. Epidemiol Infect 1992; 109: 35-47.

32. Bamford KB, Bickley J, Collins JSA et al. Helicobacter pylori: comparison of DNA fingerprints provides evidence for intrafamilial infection. Gut $1993 ; 34$ : 1348-1350.

33. Mackay GA, Pearce FL. A comparison of rat peritoneal mast cells purified using Percoll and Path-O-Cyte 4. Agents Actions 1992; Special Conference Issue: C315-C317. 
34. Denizot Y, Sobhani I, Rambaud J-C, Lewin M, Thomas Y, Benveniste J. Paf-acether synthesis by Helicobacter pylori. Gut 1990; 31: 1242-1245.

35. Engstrand L, Scheynius A, Påhlson C, Grimelius L, Schwan A, Gustavsson S. Association of Campylobacter pylori with induced expression of class II transplantation antigens on gastric epithelial cells. Infect Immun 1989; 57: 827-832.

36. Engstrand L, Scheynius A, Pahlson C. Presence of $65 \mathrm{kDa}$ heat shock protein in gastric epithelial cells; an antigen for gamma/delta $\mathrm{T}$ cells in Helicobacter pylori associated gastritis. Rev Esp Enferm Dig 1990; 78 Suppl 1: 4.

37. Karttunen $\mathrm{R}$, Andersson $\mathrm{K}$, Poikonen $\mathrm{K}$ et al. Helicobacter pylori induces lymphocyte activation in peripheral blood cultures. Clin Exp Immunol 1990; 82: 485-488.

38. Crabtree JE, Shallcross TM, Heatly RV, Wyatt JI. Interleukin 6 and tumor necrosis factor alpha secretion by Helicobacter pylori colonised gastric mucosa. Rev Esp Enferm Dig 1990; 78 Suppl 1:5-6.

39. Karttunen R. Blood lymphocyte proliferation, cytokine secretion and appearance of $T$ cells with activation surface markers in cultures with Helicobacter pylori. Comparison of the responses of subjects with and without antibodies to H. pylori. Clin Exp Immunol 1991; 83: 396-400.

40. Knipp U, Birkholz S, Kaup W, Opferkuch W. Immune suppressive effects of Helicobacter pylori on human peripheral blood mononuclear cells. Med Microbiol Immunol 1993; 182: 63-76.

41. Knipp U, Birkholz S, Kaup W, Mahnke K, Opferkuch W. Suppression of human mononuclear cell response by Helicobacter pylori: effects on isolated monocytes and lymphocytes FEMS Immunol Med Microbiol 1994; 8: $157-166$. 